\title{
Levels of Octachlorostyrene in Mothers' Milk and Potential Exposure Among Infants in Sendai City, Japan 2012
}

\author{
Sani Rachman Soleman ${ }^{1,2}$, Tomoko Fujitani ${ }^{1}\left[\right.$, Yukiko Fujii ${ }^{3}{ }^{\mathbb{D}}$ and Kouji H. Harada ${ }^{1, *}$ \\ 1 Department of Health and Environmental Sciences, Kyoto University Graduate School of Medicine, \\ Kyoto 606-8501, Japan; sani.soleman.67s@st.kyoto-u.ac.jp (S.R.S.); fujitani.tomoko.4w@kyoto-u.ac.jp (T.F.) \\ 2 Faculty of Medicine, Universitas Islam Indonesia, Yogyakarta 55584, Indonesia \\ 3 Department of Pharmaceutical Sciences, Daiichi University of Pharmacy, Fukuoka 815-8511, Japan; \\ yu-fujii@umin.ac.jp \\ * Correspondence: kharada-hes@umin.ac.jp
}

Received: 31 March 2020; Accepted: 26 April 2020; Published: 28 April 2020

\begin{abstract}
Persistent organic pollutants can accumulate inside the human body, including in mothers' milk, which may affect infant development. This cross-sectional study aimed to examine selected persistent organic pollutants in the milk of 100 mothers in Sendai city, Miyagi Prefecture, Japan. We used gas-chromatography-electron capture negative chemical ionization-mass spectrometry to check for octachlorostyrene, dechlorane (Dec) plus, Dec 602, Dec 603, and Dec 604. Octachlorostyrene was detected in 86 samples at more than the method detection limit $\left(84 \mathrm{pg} \mathrm{g-lipid}^{-1}\right)$ but no dechloranes were above the method detection limit $\left(1 \mathrm{ng} \mathrm{mL}^{-1}\right.$ for dechlorane plus, Dec 602, and Dec 603; $20 \mathrm{ng} \mathrm{mL}^{-1}$ for Dec 604). The mean octachlorostyrene concentration was $461 \mathrm{pg} \mathrm{g}$-lipid $^{-1}$, the median was $337 \mathrm{pg} \mathrm{g}$-lipid $^{-1}$, and the standard deviation $450 \mathrm{pg} \mathrm{g-lipid}^{-1}$. No baseline characteristics were associated with octachlorostyrene level except for mother's occupation (stay-at-home mother, $353 \pm 327$ pg g-lipid $^{-1}$; others, $531 \pm 509$ pg g-lipid $\left.^{-1}\right)$. Octachlorostyrene was also significantly negatively correlated with lipid content $(\mathrm{r}=-0.35, p=0.0004)$. However, the maximum intake of octachlorostyrene among infants in this study $(3.5 \mathrm{ng} / \mathrm{kg} /$ day) was under the acceptable daily intake $(30 \mathrm{ng} / \mathrm{kg} /$ day, derived from $12-$ month study in rats), and is therefore unlikely to pose a health risk.
\end{abstract}

Keywords: octachlorostyrene; lipid content; mother's milk; persistent organic pollutants

\section{Introduction}

Harmful substances have been used in Japan and can impact the environment and pose human health hazards [1]. Persistent organic pollutants (POPs) are organic chemical compounds that accumulate in lipid metabolism systems, disrupting hormonal processes. Particularly harmful are the so-called endocrine-disrupting chemicals [2]. Exposure to POPs has been widely evaluated [2].

Octachlorostyrene (OCS) is a persistent and bioaccumulative toxicant with halogenated aromatic components. Non-oncogenic effects of OCS have been found in liver cells via oxidative stresses [3,4]. OCS has also been reported to induce metabolic activation via an aryl hydrocarbon receptor and constitutive androstane receptor, and therefore could be a potential endocrine disruptor [5]. It is a primary level 1 chemical, as categorized by the Canada Ontario Agreement on Great Lake Water Quality and Ecosystem Health (COA) in 2014 [3]. Level 1 chemicals are persistent, bioaccumulative, toxic and of immediate environmental concern to the Great Lake Basin. OCS is created as a by-product of industrial manufacturing processes involving chlorine. It has never been commercially used, but is widely distributed in the environment. In industrial manufacturing, OCS originates from production of magnesium and chlorinated solvents, aluminum plasma etching, aluminum degassing 
with hexachloroethane, chlorination of titanium, and waste incineration. Environmental concern about chlorinated aromatic compounds is widespread [6], but there is little information available about how these are contaminated with OCS and released to the environment. OCS has been found in several media including sediment, fish, marine products, and human blood [7]. Sediment samples from Calcasieu Lake in the USA showed $360 \mathrm{ng} / \mathrm{g}$ of OCS, while those from other lakes were around $0.2 \mathrm{ng} / \mathrm{g}$ [8]. One study found high concentrations in aquatic organisms (mean $0.06 \mathrm{ng} / \mathrm{g}$ in zebra mussels from Europe; mean $0.53 \mathrm{ng} / \mathrm{g}$ in cod liver oil in the United Kingdom) [7]. Fish consumption might be one exposure sources to OCS. Other studies have reported OCS in human blood ( $54.6 \mathrm{ng} / \mathrm{g}$ lipid in aluminum foundry workers in Sweden) and breast milk $(0.18 \mathrm{ng} / \mathrm{g}$ lipid in healthy mothers from Denmark and Finland) [9,10].

Other emerging halogenated compounds are chlorinated flame retardants such as dechloranes (Decs). Decs were developed as substitutes for Mirex that were already regulated as POPs, and Decs are also considered as a persistent substance. Environmental contamination in aquatic systems by Decs has been reported [11]. Among several Decs, dechlorane plus (DP) was included in the Candidate List of substances of very high concern for authorization [12]. It was detected in human breast milk samples along with OCS in several cities $[13,14]$. Few studies are available on the toxicities, but expression of metabolic enzymes was induced [15]. OCS's structural similarity to Mirex warrants further investigation.

These lipophilic compounds are accumulative in adipose tissues and breast milk. There is little information on internal burdens of OCS in humans. Exposure levels in humans needs investigation. In addition, factors affecting the exposure to OCS will be useful to reduce the exposure. Hence, the objective of this study was to examine OCS and Decs in breast milk of Japan, in Miyagi prefecture, and estimate exposure to detected OCS among infants. This study may help to assess the potential risk among an affected or vulnerable population. Moreover, the levels of detected OCS were compared with participant's characteristics such as age, occupation, and fish intake to explore the related factors.

\section{Materials and Methods}

\subsection{Study Participants}

Breast milk samples were collected from mothers who gave birth at a general hospital in Sendai City, Miyagi Prefecture from June to December, 2012. They are a part of the samples in the Kyoto Human Specimen Bank, which uses a standardized protocol [16]. Briefly, approximately $300 \mathrm{~g}$ of breast milk were collected from lactating women within 2 months after delivery (average $326 \mathrm{~g}$ ranging from $93 \mathrm{~g}$ to $400 \mathrm{~g}$ ). The hospital reported 1229 deliveries in 2012, and 100 samples were used for chemical analysis of environmental pollutants. Mothers were also asked to answer a questionnaire on their characteristics. Written consent was obtained from all mothers. The protocol for this study was approved by the Ethics Committee of Kyoto University Graduate School of Medicine and Faculty of Medicine and Hospital (Approval number E25 on Feb 1st, 2010, 'Human exposure monitoring and risk assessment'). Samples were analyzed by gas-chromatography-electron capture negative chemical ionization-mass spectrometry (GC-ECNI-MS) to detect substances that had not previously been monitored, and to identify the current state of environmental pollution.

\subsection{Chemicals}

We looked at levels of OCS, dechlorane plus (DP), Dec 602, Dec 603, and Dec 604. Syn-DP, anti-DP, and OCS (ULM-4559) were purchased from Cambridge Isotope Laboratories (Tewksbury, MA). Dec 602 (95\%), Dec 603 (98\%), and Dec 604 (98\%) were purchased from Toronto Research Chemical Inc. (Toronto, ON, Canada). ${ }^{13} \mathrm{C}_{6}$ - hexachlorobenzene (manufactured by CIL) was used as a recovery surrogate substance. ${ }^{13} \mathrm{C}_{12}-2,3,3^{\prime}, 5,5^{\prime}$-pentachlorobiphenyl (CB-111, manufactured by CIL) was used as an internal standard for quantification. Isopropanol, diethyl ether, hexane, nonane, and 
dichloromethane were used for pesticide residue tests and polychlorinated biphenyl tests (Kanto Chemical Co., Ltd., Tokyo, Japan). The Florisil was made by Wako Pure Chemical (Osaka, Japan).

\subsection{Extraction and Purification of Samples}

The milk sample was stirred, and $5 \mathrm{~mL}$ was separated into a polypropylene centrifuge tube. Then, $9 \mathrm{~mL}$ extraction solvent (2:1:3 (vol/vol/vol) isopropanol/diethyl ether/hexane), with a carbon 13-labeled hexachlorobenzene ( $500 \mathrm{pg}$ ) was added to the sample as a recovery standard, and samples were vortexed and centrifuged. The organic layer was transferred to a flask, and the extraction operation was repeated by adding another $8 \mathrm{~mL}$ of extraction solvent. The combined organic layers were concentrated using a rotary evaporator. The crude extract was diluted in $10 \mathrm{~mL}$ of hexane using a volumetric flask. An aliquot was divided, and the lipid weight was weighed. Distilled water was added to the crude extract, vortexed, centrifuged, and the aqueous layer was removed. Then, $10 \mathrm{~mL}$ of the crude extract was added dropwise to an $8 \mathrm{~g}$ activated Florisil column (Florisil PR, manufactured by Wako Pure Chemical Industries). Target analytes were eluted with $20 \mathrm{~mL}$ of hexane (first fraction containing OCS) with the loading solution, and $40 \mathrm{~mL}$ of a $10 \%$ dichloromethane/hexane solution (second fraction containing Dec). The eluate was concentrated to about $1 \mathrm{~mL}$ using a rotary evaporator. After concentrating to $0.1 \mathrm{~mL}$ of nonane, internal standard ${ }^{13} \mathrm{C}_{12}$-labeled CB-111 (10 ng) was added and the sample was subjected to GC/MS analysis.

\subsection{Chemical Analysis}

Agilent 6890GC/5973MS was used. The capillary column was made of HP-5MS and had a total length of $30 \mathrm{~m}$, an inner diameter of $0.25 \mathrm{~mm}$, and a film thickness of $0.25 \mu \mathrm{m}$. The carrier gas was

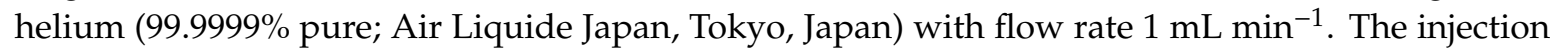
volume was $1.0 \mu \mathrm{L}$. The injector was used in splitless mode, with the vent opened at $1 \mathrm{~min}$. The injector temperature was $280^{\circ} \mathrm{C}$. The oven temperature program started at $70^{\circ} \mathrm{C}$ for $1.5 \mathrm{~min}$, then increased at $20^{\circ} \mathrm{C} \mathrm{min}-1$ to $230^{\circ} \mathrm{C}$, then at $4{ }^{\circ} \mathrm{C} \mathrm{min}^{-1}$ to $280^{\circ} \mathrm{C}$. Substances were measured by negative ion chemical ionization using methane gas. The ion source, triple-quadrupole, and transfer line temperatures were 150,100 , and $280^{\circ} \mathrm{C}$, respectively. The $\mathrm{m} / \mathrm{z} 380$ was used for quantification of OCS. DP, Dec 602, Dec 603, and Dec 604 were quantified using $\mathrm{m} / \mathrm{z}$ 654, 614, 638, and 614, respectively. ${ }^{13} \mathrm{C}_{12}$-labeled CB-111, hexachlorobenzene, and DP were monitored by $\mathrm{m} / \mathrm{z} 340,290$, and 664 , respectively. The instrumental limit of detection (IDL) was defined as a $\mathrm{S} / \mathrm{N}$ ratio of 3 . Using a blank sample, contamination in the extraction and purification was evaluated. Signals were below IDL in the blank sample, so the method detection limit (MDL) was equal to the IDL. Recoveries of standard-spiked samples (200 pg for OCS, $20 \mathrm{ng}$ for DP, Dec 602, and Dec 603, and $500 \mathrm{ng}$ for Dec 604, $n=5$ ) were 96\% for OCS and $92 \%-98 \%$ for Dec.

\subsection{Statistical Analysis}

Levels less than the MDL were converted to half of the MDL. The normality of the data was tested using the Kolmogorov-Smirnov method. An independent $t$-test was used to examine the differences in OCS levels by baseline characteristics. Multiple regression analyses were used to examine correlations between OCS and maternal and infant characteristics. SPSS Statistics 23 (IBM, Chicago, IL, USA) was used for these calculations.

\section{Results and Discussion}

Among 100 samples, 98 mothers responded to the questionnaire. Maternal characteristics are summarized in Table 1. The mothers' mean age was 30 years old. The biggest groups in each category were stay-at-home mothers (36\%), nulliparous $(60 \%)$, vaginal delivery $(57 \%)$, and never smoked $(70 \%)$. Birth outcomes in this study were comparable to those in Japan [17]. There was no available data on fish intake among breast feeding mothers, but the levels of fish intake among pregnant women 
( $29.1 \mathrm{~g} /$ day) was lower than current participants [18]. This could be due to a difference in the food frequency questionnaires.

Table 1. Baseline characteristic of respondents at sampling of breast milk.

\begin{tabular}{|c|c|}
\hline Characteristics & $n(\%)$ \\
\hline \multicolumn{2}{|l|}{ Occupation } \\
\hline Clerical workers & $19(19)$ \\
\hline Stay-at-home mother & $36(36)$ \\
\hline Medical practitioner & $17(17)$ \\
\hline Service officer & $25(25)$ \\
\hline NA & $3(3)$ \\
\hline \multicolumn{2}{|l|}{ Method of delivery } \\
\hline Cesarean & $28(28)$ \\
\hline Suction & $13(13)$ \\
\hline Vaginal & $57(57)$ \\
\hline NA & $2(2)$ \\
\hline \multicolumn{2}{|l|}{ Sex of infants } \\
\hline Male & $50(50)$ \\
\hline Female & $48(48)$ \\
\hline NA & $2(2)$ \\
\hline \multicolumn{2}{|l|}{ Second-hand smokers } \\
\hline Husband & $9(9)$ \\
\hline No & 87 (87) \\
\hline Parents & $2(2)$ \\
\hline NA & $2(2)$ \\
\hline \multicolumn{2}{|l|}{ Parity } \\
\hline Nulliparous & $58(58)$ \\
\hline Multiparous 1 & $29(29)$ \\
\hline 2 & $8(8)$ \\
\hline 3 & $3(3)$ \\
\hline NA & $2(2)$ \\
\hline \multicolumn{2}{|l|}{ Smoking } \\
\hline Never & $69(69)$ \\
\hline Ex smoking & $28(28)$ \\
\hline Current & $1(1)$ \\
\hline NA & $2(2)$ \\
\hline \multicolumn{2}{|l|}{ Drinking alcohol } \\
\hline Never & $29(29)$ \\
\hline Ex drinking & $68(56)$ \\
\hline Current & $0(0)$ \\
\hline NA & $3(2)$ \\
\hline \multicolumn{2}{|l|}{ Living near busy road } \\
\hline Yes & $50(50)$ \\
\hline No & $46(46)$ \\
\hline \multirow[t]{2}{*}{ NA } & $4(4)$ \\
\hline & $($ mean $\pm S D)$ \\
\hline Age (yr) & $30 \pm 6.6$ \\
\hline Height (cm) & $156 \pm 22.9$ \\
\hline Weight (kg) & $54.9 \pm 10.5$ \\
\hline Weight before pregnancy (kg) & $51.4 \pm 10.3$ \\
\hline Birth weight (g) & $2993 \pm 640$ \\
\hline Birth length (cm) & $45.5 \pm 11.8$ \\
\hline Fish intake (g/day) & $45.3 \pm 36.2$ \\
\hline
\end{tabular}

NA: not applicable due to missing records. Smokers ('current' and 'ex smoking') had 4.2 pack-years (SD 4.0). Ex-drinker of alcohol had 5.3 g-ethanol/d (SD 6.2). 
OCS was detected in 86 samples at more than the MDL ( $84 \mathrm{pg}$ g-lipid ${ }^{-1}$ ). OCS concentration had a mean of 461 pg g-lipid ${ }^{-1}$, median of 337, and standard deviation of 450 (Table 2). The distribution followed a log-normal distribution. The levels were slightly higher than those reported in Finland and Denmark [8], suggesting that Japanese mothers may have higher exposure to OCS.

Table 2. Distribution of octachlorostyrene (OCS) levels (pg g-lipid $\left.{ }^{-1}\right)$ among participants $(N=100)$.

\begin{tabular}{cccccc}
\hline & Mean & Median & SD & Min & Max \\
\hline OCS & 461 & 337 & 450 & $<84$ & 3186 \\
\hline
\end{tabular}

No dechloranes were found above the MDL ( $1 \mathrm{ng} \mathrm{mL}^{-1}$ for DP, Dec 602, and Dec 603; $20 \mathrm{ng} \mathrm{mL}^{-1}$ for Dec 604) and so were excluded from further analyses. DP levels in the Japanese environment were reported $[19,20]$, and they were shown to be comparable to or lower than those in other countries. In addition, milk/serum ratio of DP was less than 1 [21]. Hence, a large sample volume would be required to detect Decs.

The association between OCS and maternal characteristics is shown in Table 3. Participants were divided into two groups by status or median values. Those with occupations other than stay-at-home mother had higher OCS levels. This finding suggests that OCS levels in the home environment may be lower than in the workplace or that there may be occupational exposures to OCS. Since we have only two categories of occupation (stay-at-home mother and other), it is difficult to identify the distinct exposure sources in this study. As mentioned before, OCS can be a by-product in chemical processes, but the exposure routes in the general population should be investigated. Lipid content was negatively associated with OCS level (Pearson's $r=-0.35, p=0.0004$ ). Partition of OCS to breast milk could therefore be less fat-dependent.

Table 3. Association between OCS and maternal characteristics at the collection of samples.

\begin{tabular}{|c|c|c|c|}
\hline Characteristic & $n$ & $\begin{array}{c}\text { OCS }(p g \text { g-lipid } \\
\text { Mean } \pm \text { SD }\end{array}$ & $p$ Value * \\
\hline \multicolumn{4}{|l|}{ Age at delivery } \\
\hline$<32 \mathrm{yr}$ & 52 & $519 \pm 551$ & \multirow{2}{*}{0.50} \\
\hline$\geq 32 \mathrm{yr}$ & 46 & $402 \pm 306$ & \\
\hline \multicolumn{4}{|l|}{ Occupation } \\
\hline stay-at-home mother & 36 & $353 \pm 327$ & \multirow[b]{2}{*}{$0.03 *$} \\
\hline others & 61 & $531 \pm 509$ & \\
\hline \multicolumn{4}{|l|}{ Parity } \\
\hline nulliparous & 60 & $478 \pm 492$ & \multirow{2}{*}{0.74} \\
\hline multiparous & 40 & $445 \pm 398$ & \\
\hline \multicolumn{4}{|l|}{ Delivery method } \\
\hline vaginal & 57 & $513 \pm 509$ & \multirow{2}{*}{0.23} \\
\hline others & 41 & $410 \pm 370$ & \\
\hline \multicolumn{4}{|l|}{ Weight before pregnancy } \\
\hline$<52 \mathrm{~kg}$ & 54 & $472 \pm 515$ & \multirow{2}{*}{0.91} \\
\hline$\geq 52 \mathrm{~kg}$ & 44 & $462 \pm 373$ & \\
\hline \multicolumn{4}{|l|}{ Age at first delivery } \\
\hline$<29 \mathrm{yr}$ & 53 & $504 \pm 538$ & \multirow{2}{*}{0.59} \\
\hline$\geq 29 \mathrm{yr}$ & 45 & $417 \pm 330$ & \\
\hline \multicolumn{4}{|l|}{ Gestational week } \\
\hline$<39$ week & 53 & $453 \pm 355$ & \multirow{2}{*}{0.7} \\
\hline$\geq 39$ week & 42 & $454 \pm 536$ & \\
\hline
\end{tabular}


Table 3. Cont.

\begin{tabular}{cccc}
\hline Characteristic & $n$ & $\begin{array}{c}\left.\text { OCS (pg g-lipid }{ }^{-1}\right) \\
\text { Mean } \pm \text { SD }\end{array}$ & $p$ Value * \\
\hline $\begin{array}{c}\text { Fish intake } \\
<40 \text { g/day }\end{array}$ & 49 & $482 \pm 528$ & 0.66 \\
$\geq 40$ g/day & 49 & $446 \pm 371$ & \\
\hline Lipid content (\%) & 51 & $594 \pm 561$ & \\
$<2.34$ & 49 & $322 \pm 227$ & 0.01 \\
$\geq 2.34$ & 49 & & 0.43 \\
BMI & 49 & $460 \pm 512$ & \\
$<22$ & & $468 \pm 394$ & \\
$\geq 22$ & 69 & $486 \pm 490$ & \\
\hline Smoking & 29 & $413 \pm 359$ & 0.99 \\
No & & & \\
Yes & 29 & $458 \pm 391$ & \\
\hline Drinking alcohol & 68 & $470 \pm 484$ & \\
Yes & 46 & $489 \pm 537$ & \\
\hline Living near busy road & 50 & $422 \pm 341$ & \\
No & & & \\
\hline
\end{tabular}

* Independent $t$-test. Participants were divided into two groups by status or median values. Missing data in each variable were excluded from analysis.

Associations between OCS and infant characteristics are shown in Table 4. None of the variables showed any significant differences.

Table 4. Association between OCS and infant characteristics.

\begin{tabular}{|c|c|c|c|}
\hline Characteristic & $n$ & $\begin{array}{c}\text { OCS }(\text { pg g-lipid-1) } \\
\text { Mean } \pm \text { SD }\end{array}$ & $p$ Value * \\
\hline \multicolumn{4}{|l|}{ Sex of infants } \\
\hline Female & 48 & $428 \pm 357$ & \multirow{2}{*}{0.43} \\
\hline Male & 50 & $499 \pm 533$ & \\
\hline \multicolumn{4}{|l|}{ Birth weight } \\
\hline$<3041 \mathrm{~g}$ & 49 & $469 \pm 529$ & \multirow{2}{*}{0.86} \\
\hline$\geq 3041 \mathrm{~g}$ & 49 & $460 \pm 371$ & \\
\hline \multicolumn{4}{|l|}{ Birth length } \\
\hline$<49 \mathrm{~cm}$ & 56 & $436 \pm 397$ & \multirow{2}{*}{0.55} \\
\hline$\geq 49 \mathrm{~cm}$ & 38 & $481 \pm 541$ & \\
\hline
\end{tabular}

* Independent $t$-test. Participants were divided into two groups by status or median values. Missing data in each variable were excluded from analysis.

Finally, multiple regression analysis was used to identify potential factors affecting OCS levels in breast milk. Table 5 shows the five models evaluated. Only lipid content of breast milk was negatively associated with OCS level ( $p$ value $<0.001$ ). However, $\mathrm{R}^{2}$ was $9.8 \%$ and lipid content cannot fully explain the OCS levels. 
Table 5. Multiple regression analysis of OCS level.

\begin{tabular}{|c|c|c|c|c|c|}
\hline & Model & $\begin{array}{l}\text { Unstandardized } \\
\text { Coefficients }\end{array}$ & Std. Error & Coefficients & $p$ Value * \\
\hline \multirow{6}{*}{ Model 1} & (constants) & 87.564 & 53.232 & & 0.10 \\
\hline & Weight before pregnancy & 0.974 & 2.582 & 0.053 & 0.71 \\
\hline & Gestational week & -5.324 & 7.381 & -0.076 & 0.47 \\
\hline & Fish intake & -0.139 & 0.378 & -0.038 & 0.71 \\
\hline & Lipid contents & -91.190 & 26.582 & -0.354 & $<0.001 *$ \\
\hline & BMI & -5.796 & 4.496 & -0.175 & 0.20 \\
\hline \multirow{5}{*}{ Model 2} & (constants) & 88.298 & 52.929 & & 0.10 \\
\hline & Weight before pregnancy & 0.750 & 2.497 & 0.041 & 0.76 \\
\hline & Gestational week & -5.500 & 7.329 & -0.079 & 0.46 \\
\hline & Lipid contents & -90.209 & 26.316 & -0.350 & $<0.001 *$ \\
\hline & BMI & -5.599 & 4.442 & -0.169 & 0.21 \\
\hline \multirow{4}{*}{ Model 3} & (constants) & 92.237 & 51.051 & & 0.07 \\
\hline & Gestational week & -5.900 & 7.170 & -0.084 & 0.41 \\
\hline & Lipid contents & -90.878 & 26.086 & -0.353 & $<0.001 *$ \\
\hline & BMI & -4.731 & 3.357 & -0.143 & 0.16 \\
\hline \multirow{3}{*}{ Model 4} & (constants) & 52.450 & 16.241 & & 0.002 \\
\hline & Lipid contents & -87.137 & 25.640 & -0.338 & $<0.001 *$ \\
\hline & BMI & -4.217 & 3.292 & -0.127 & 0.20 \\
\hline \multirow{2}{*}{ Model 5} & (constants) & 32.296 & 4.043 & & $<0.001$ \\
\hline & Lipid contents & -84.669 & 25.658 & -0.329 & $<0.001$ * \\
\hline
\end{tabular}

Backward stepwise selection of variables was conducted. Variable with highest $p$ value was eliminated from the model at each step. $\mathrm{R}^{2}=9.8 \%$ for Model $5 .{ }^{*} p$-value is significant based on multiple regression analysis.

After ingestion of POPs into the gastrointestinal tract, they can be deposited in adipose tissue via lipoproteins, increasing the risk of cardiovascular disease [22]. A number of studies have clearly explained the association of POPs with alterations in lipid metabolism in both animals and people [23,24]. A study also demonstrated that prolonged exposure to polychlorinated biphenyls was correlated with lipid alteration [25]. This study found that OCS was significantly inversely correlated with lipid content of breast milk. The finding is similar to another study suggesting that organochlorine pesticides were inversely related to low density lipoprotein cholesterol levels in participants [23]. It is unclear whether OCS reduces the lipid content or a decrease in lipid content results in increased OCS concentration per lipid. If OCS causes changes in the lipid content of breast milk, it should be a concern to mothers, especially those breastfeeding. Toxicological investigation is required to explain the relationship. Moreover, the OCS exposure to fetuses may cause congenital disease [8]. Many researches have focused on the endocrine-disrupting effects of POPs, including OCS, affecting reproductive health in offspring, such as cryptorchidism [8].

We also calculated exposure to OCS among infants via breastfeeding. Consumption of breast milk was assumed to be $600 \mathrm{~g} /$ day and body weight of 1-year-old infants was set as $7.3 \mathrm{~kg}$, in line with published figures [26].

The estimate of OCS intake is shown in Table 6. In this study population, the mean exposure of infants to OCS was $804 \mathrm{pg} / \mathrm{kg} /$ day, with a maximum of $3473 \mathrm{pg} / \mathrm{kg} /$ day.

Table 6. Estimation of OCS intake among breastfed infants (1 year old).

\begin{tabular}{cccccc}
\hline \multicolumn{6}{c}{ OCS Intake (pg/kg/day) } \\
\hline Mean & SD & Median & 75th percentile & 97.5th percentile & Max \\
\hline 804 & 624 & 722 & 1064 & 2766 & 3473 \\
\hline
\end{tabular}


A report from New York State suggests that the acceptable daily intake (ADI) of OCS is $30 \mathrm{ng} / \mathrm{kg} /$ day [27]. Maximum intake in this study was therefore under this limit, and there is likely to be little risk to health. However, it should be noted that the estimate assumed constant levels of OCS during lactation. OCS concentrations in breast milk might change due to body weight change in mothers and elimination of OCS via breastfeeding. In addition, ADI was based on histological changes in liver, thyroid, and kidney in a 12-month dietary study in rats [28]. Even though ADI was calculated with an uncertainty factor of 1000, developmental effects would be considered in the population. Hence, the estimate has an uncertainty. Few epidemiological studies have examined the effects of OCS exposure on infant health. Further toxicological and epidemiological studies are required because mothers are still being exposed to OCS.

In this study, factors other than occupation and lipid content showed no association with OCS levels in breast milk. This may be partly due to the characteristics of the participants. They were relatively healthy, and their birth outcomes and habits were within normal ranges. Comparisons between poor and normal outcomes might be required to show the possible association. On the other hand, OCS levels in this study were lower than other POPs (dichlorodiphenyltrichloroethane, $0.77-2.4 \mathrm{ng} \mathrm{glipid}^{-1}$; polychlorinated biphenyls, $129 \mathrm{ng}$ glipid $^{-1}$ ) in the same location $[29,30]$. The possible effects of OCS might be masked with those from other POPs. Available data on levels of OCS in human samples are scarce, especially for breast milk, and it is not clear if the infants outside Japan are at safe levels. This study analyzed breast milk samples collected in 2012. Significant temporal change in exposure is unlikely, but we recommend a prospective study to predict OCS exposure on birth outcome among infants. Finally, a comprehensive evaluation and monitoring OCS level with other POPs should be conducted to prevent health effects of OCS among breastfeeding mothers and their infants.

\section{Conclusions}

OCS was detected in most breastmilk samples from Japanese mothers, and the levels were inversely correlated with lipid content. However, the estimated intake for infants in a city in Japan was lower than the current acceptable daily intake.

Author Contributions: Conceptualization, K.H.H.; Data curation, S.R.S., Y.F., K.H.H.; Funding acquisition, K.H.H.; Resources, K.H.H.; Writing—original draft, S.R.S.; Writing—review and editing, T.F., Y.F., K.H.H. All authors have read and agreed to the published version of the manuscript.

Funding: This study was supported by Grants-in-Aid for Scientific Research from the Japan Society for the Promotion of Science (JSPS) (Grants 23590739 and 20H03930) and a JSPS and NRF of Korea bilateral joint research project.

Acknowledgments: We thank Melissa Leffler, MBA, from Edanz Group (https://en-author-services.edanzgroup. $\mathrm{com} /$ ) for editing a draft of this manuscript.

Conflicts of Interest: The authors declare no conflict of interest.

\section{References}

1. Hibiki, A.; Managi, S. Environmental information provision, market valuation, and firm incentives: An empirical study of the Japanese PRTR system. Land Economics 2010, 86, 382-393. [CrossRef]

2. Carpenter, D.O. Health effects of persistent organic pollutants: The challenge for the Pacific Basin and for the world. Rev. Environ. Health 2011, 26, 61-69. [CrossRef] [PubMed]

3. The Canada Ontario Agreement on Great Lake Water Quality and Ecosystem Health in 2014. Available online: https://www.ontario.ca/page/canada-ontario-great-lakes-agreement. (accessed on 13 April 2020).

4. Park, E. Park, K. Induction of oxidative stress in human Chang liver cells by octachlorostyrene, the persistent and bioaccumulative toxicant. Toxicol. in vitro 2008, 22, 367-375. [CrossRef] [PubMed]

5. Yanagiba, Y.; Ito, Y.; Kamijima, M.; Gonzalez, F.J.; Nakajima, T. Octachlorostyrene Induces Cytochrome P450, UDP-glucuronosyltransferase, and Sulfotransferase via the Aryl Hydrocarbon Receptor and Constitutive Androstane Receptor. Toxicol. Sci. 2009, 111, 19-26. [CrossRef] 
6. Greenlee, W.F.; Osborne, R.; Dold, K.M.; Hudson, L.G.; Toscano, W.A. Toxicity of Chlorinated Aromatic Compounds in Animals and Humans: In Vitro Approaches to Toxic Mechanisms and Risk Assessment. Environ. Health Perspect. 1985, 60, 69-76. [CrossRef]

7. Chu, S.; Covaci, A.; Voorspoels, S.; Schepen, S. The distribution of octachlorostyrene (OCS) in environmental samples from Europe. J. Environ. Monit. 2003, 5, 619-625. [CrossRef]

8. Kaminsky, R.; Hites, R.A. Octachlorostyrene in Lake Ontario: Sources and fates. Environ. Sci. Technol. 1984, 18, 275-279. [CrossRef]

9. Selden, A.I.; Nygren, Y.; Westberg, H.B. Hexachlorobenzene and octachlorostyrene in plasma of aluminium foundry workers using hexachloroethane for degassing. Occup. Environ. Med. 1997, 54, 613-618. [CrossRef]

10. Damgaard, I.; Skakkebaek, N.; Toppari, J.; Virtanen, H.; Shen, H.; Schramm, K.; Petersen, J.; Jensen, T.; Main, K.; Nordic Cryptorchidism Study Group. Persistent pesticides in human breast milk and crypthorchidism. Environ. Health Perspect. 2006, 114, 1133-1138. [CrossRef]

11. Zhu., H.; Hites, R.A. Dechlorane Plus, a chlorinated flame retardant, in the Great Lakes. Environ. Sci. Technol. 2006, 40, 1184-1189. [CrossRef]

12. European Chemicals Agency. Candidate List of Substances of Very High Concern for Authorisation. 2018. Available online: https://echa.europa.eu/candidate-list-table/-/dislist/details/0b0236e181f392bf (accessed on 20 February 2020).

13. Siddique, S.; Xian, Q.; Abdelouahab, N.; Takser, L.; Phillips, S.P.; Feng, Y.L.; Wang, B.; Zhu, J. Levels of dechlorane plus and polybrominated diphenylethers in human milk in two Canadian cities. Environ. Int. 2012, 39, 50-55. [CrossRef] [PubMed]

14. Zhou, S.N.; Siddique, S.; Lavoie, L.; Takser, L.; Abdelouahab, N.; Zhu, J. Hexachloronorbornene-based flame retardants in humans: Levels in maternal serum and milk. Environ Int. 2014, 66, 11-17. [CrossRef] [PubMed]

15. Li, Y.; Yu, L.; Wang, J.; Wu, J.; Mai, B.; Dai, J. Accumulation pattern of Dechlorane Plus and associated biological effects on rats after $90 \mathrm{~d}$ of exposure. Chemosphere 2013, 90, 2149-2156. [CrossRef]

16. Koizumi, A.; Harada, K.H.; Inoue, K.; Hitomi, T.; Yang, H.R.; Moon, C.S.; Wang, P.; Hung, N.N.; Watanabe, T.; Shimbo, S.; et al. Past, Present, and Future of Environmental Specimen Banks. Environ. Health Prev. Med. 2009, 14, 307-318. [CrossRef]

17. Ogawa, Y.; Iwamura, T.; Kuriya, N.; Nishida, H.; Takeuchi, H.; Takada, M. Birth size standards by gestational age for Japanese neonates. Acta Neonatol. Japonica. 1998, 34, 624-632.

18. Saito, S.; Kawabata, T.; Tatsuta, N.; Kimura, F.; Miyazawa, T.; Mizuno, S.; Nishigori, H.; Arima, T.; Kagawa, Y.; Yoshimasu, K.; et al. Determinants of polyunsaturated fatty acid concentrations in erythrocytes of pregnant Japanese women from a birth cohort study: Study protocol and baseline findings of an adjunct study of the Japan environment \& Children's study. Environ. Health Prev. Med. 2017, 22, 22. [CrossRef]

19. Minomo, K.; Nojiri, K.; Motegi, M.; Ohtsuka, N.; Horii, Y. Dechlorane Plus and Related Compounds in Ambient Air from Saitama, Japan. J. Environ. Chem. 2016, 26, 53-59. [CrossRef]

20. Sakiyama, T.; Nakano, T. Environmental Levels of a Chlorinated Flame Retardant, Dechlorane Plus in Japan. J. Environ. Chem. 2016, 26, 77-88. [CrossRef]

21. Ben, Y.J.; Li, X.H.; Yang, Y.L.; Li, L.; Di, J.P.; Wang, W.Y.; Zhou, R.F.; Xiao, K.; Zheng, M.Y.; Tian, Y.; et al. Dechlorane Plus and its dechlorinated analogs from an e-waste recycling center in maternal serum and breast milk of women in Wenling, China. Environ. Pollut. 2013, 173, 176-181. [CrossRef]

22. Goncharov, A.; Haase, R.F.; Santiago-Rivera, A.; Morse, G.; McCaffrey, R.J.; Rej, R.; Carpenter, D.O. High serum PCBs are associated with elevation of serum lipids and cardiovascular disease in a Native American population. Environ. Res. 2008, 106, 226-239. [CrossRef]

23. Penell, J.; Lind, L.; Salihovic, S.; Bavel, B.; Lind, P.M. Persistent organic pollutants are related to the change in circulating lipid levels during a 5 year follow-up. Environ. Res. 2014, 134, 190-197. [CrossRef]

24. Damstra, T.; Page, S.; Herrman, J.; Meredith, T. Persistent organic pollutants: Potential health effects? J. Epidemiol Comm. Health 2002, 56, 824-825. [CrossRef] [PubMed]

25. Aminov, Z.; Carpenter, D.O.; Haase, R. The Effects of Polychlorinated Biphenyls on Lipid Synthesis. In Proceedings of the ISEE 22nd Annual Conference, Seoul, Korea, 28 August-1 September 2010.

26. Schecter, A.; Sartin, J.; Wright, C.; Kelly, M.; Papke, O.; Lis, A.; Ball, M.; Olson, J.R. Congener specific level of dioxins and dibenzofurans in U.S food and estimated daily dioxin toxic equivalents intake. Environ. Health Perspect. 1994, 102, 962-968. [CrossRef] [PubMed] 
27. New York State. Human Health Fact Sheet. Ambien Water Quality Value for Protection of Sources of Potable Water. Octachlorostyrene. Department Environmental Conservation Division Water; 1994. Available online: https://www.epa.gov/sites/production/files/2015-06/documents/ny_hh_600_w_03121998.pdf (accessed on 20 February 2020).

28. Chu, I.; Villeneuve, D.C.; Secours, V.E.; Valli, V.E.; Leeson, S.; Shen., S.Y. Long-term toxicity of octachlorostyrene in the rat. Fundam. Appl. Toxicol. 1986, 6, 69-77. [CrossRef]

29. Fujii, Y.; Ito, Y.; Harada, K.H.; Hitomi, T.; Koizumi, A.; Haraguchi, K. Comparative survey of levels of chlorinated cyclodiene pesticides in breast milk from some cities of China, Korea and Japan. Chemosphere 2012, 452-457. [CrossRef] [PubMed]

30. Fujii, Y.; Haraguchi, K.; Harada, K.H.; Hitomi, T.; Inoue, K.; Itoh, Y.; Watanabe, T.; Takenaka, K.; Uehara, S.; Yang, H.R.; et al. Detection of dicofol and related pesticides in human breast milk from China, Korea and Japan. Chemosphere 2011, 82, 25-31. [CrossRef]

(C) 2020 by the authors. Licensee MDPI, Basel, Switzerland. This article is an open access article distributed under the terms and conditions of the Creative Commons Attribution (CC BY) license (http://creativecommons.org/licenses/by/4.0/). 